\title{
Heat Shock Protein Beta-8
}

National Cancer Institute

\section{Source}

National Cancer Institute. Heat Shock Protein Beta-8. NCI Thesaurus. Code C95435.

Heat shock protein beta-8 (196 aa, $22 \mathrm{kDa}$ ) is encoded by the human HSPB8 gene. This protein plays a role in the regulation of autophagy and as a protein chaperone. 